ISSN: 2165-8714

http://www.eu-jer.com/

\title{
The Role of Teaching Grammar in First Language Education*
}

\author{
Sezgin Demir** \\ Firat University, TURKEY
}

\author{
Ayse Erdogan \\ Ministry of Education, TURKEY
}

Received: October 31, 2017 - Revised: November 25, 2017 - Accepted: December 11, 2017

\begin{abstract}
Grammar; while originating from the natural structure of the language also is the system which makes it possible for different language functions meet within the body of common rules especially communication. Having command of the language used, speaking and writing it correctly require strong grammar knowledge actually. However only knowing the rules cannot be the indicator of using the language correctly and effectively. For the individual, who learns the rules of the language but cannot transform it to daily life, grammar teaching can be difficult and boring. Instead of considering grammar teaching as an independent and abstract lesson, realizing it through integrating with other learning fields will increase the effect and level of success in grammar teaching. The purpose of this research is to determine the views of first language teachers regarding teaching grammar. The study group of the research consist of 10 Turkish language teachers who work in a city in Turkey (Elazig). Within this research, which was carried out with qualitative pattern, the data was gathered with one on one interview technique using semi structured interview form, which consisted of 10 questions. The data gathered was analyzed with content analysis and interpreted being categorized. Regarding the findings frequency distributions were given and interpreted. As a result of the study it was seen that teaching grammar differs in terms of teachers' views, in addition in some matters they were under expectations.
\end{abstract}

Keywords: First language education, teaching grammar, language skills, communication.

To cite this article: Demir, S., \& Erdogan, A. (2018). The role of teaching grammar in first language education. European Journal of Educational Research, 7(1), 87-101. doi: 10.12973/eu-jer.7.1.87

\section{Introduction}

Language is a developed system which makes communication possible among people, enables the transformation of emotions, views and demands to others, and braided with sounds (Sagir, 2002). It can also be defined as a complement of systems and multidimensional concepts that provide the realization of the communication and constitutes from causeless symbols (Imer, Kocaman \& Ozsoy, 2013). According to Vardar (2002), language is both a sequence formed through indicatives and indicated ones come together and also a system, a mechanism that explains the operational rules of the indicators and elements produced from this combination. Language which provides communication among people is a developed, alive system and the fundamental function of the language is to provide information. Since communicational adequacy is to know how to use the grammar of the language in social order to reach communicational goals, it is primary of communicational adequacies (Zhang, 2009). Therefore the rules that take place in the functioning of the language require grammar and teaching grammar. Until school period the child, who learns his/her first language from the environment without noticing, learns the rules of the language in a system, regularly and consciously together with the school period. Moreover linguistic learnings realized without knowing and noticing the grammar rules, impose obligations to books prepared regarding this learning field to include the directions about what students must do (Xin, 2010). Grammar rules lead the individual use the language s/he can already speak in a more correct and conscious way. Besides the theories and applications that focus teaching grammar for ages in the field of language education have gained importance (Huang, 2010). School firstly takes language learning in a system; then slowly implicating the rules of the language gives them the conscious to use the language according to its rules appropriately (Sagir, 2002). Within his period teaching first language must be realized in a system without leaving up to chance.

Grammar, can be defined as the science that determines the rules of a language examining its sound, form and sentence structure (Turkce Sozluk, 2009); the information of structural rules in the functioning of the language (Imer, Kocaman \& Ozsoy, 2013); and the field of science that examines the sounds, word types and their structures, their arrangement and

\footnotetext{
* This study has been presented as an oral presentation at the conference which is "II. International Symposium on Social Sciences" organized in Alanya, Antalya-Turkey, 18-20 May 2017.

** Corresponding author:

Sezgin Demir, Faculty of Education, Firat University, Elazig, 23000, Turkey.

$\bowtie$ sezgindemir44@gmail.com
} 
functions in the sentences and also the rules concerning their conjugation (Erdem \& Celik, 2011). Without teaching grammar, which enables students discover the nature of the language through patterns that make what is said, read and heard comprehensible; the language will become a batch of words (Azar, 2007). By means of grammar rules the individual can use the language with its all components however s/he likes.

Besides grammar skill and talent help students understand the written and spoken language right and correct it, also while using the language it enables them express themselves in a correct and fluent way and provide them develop their communication skills (Li \& Song, 2007). The purpose of writing is to create sentences that are correct, complete and logic (Solikhah, 2017). At this point if grammar is being used functionally while a positive directional interaction is possible especially between writing performances, descriptive grammar, which aims defining and being defined grammatical factors, does not have a direct relation with writing skills (Fearn \& Farnan, 2007). Teaching grammar includes word attack skills in which the information about language is given and supportive, explanatory and organizer teaching techniques (Erdem \& Celik, 2011). Since it has become a routine for grammar learning domain -with a habit coming from the past- to be performed through definition/rules/example based with lectures based on memorization, teachers firstly gives the definition with traditional application and then tries to make the rule to be memorized through examples (Gocer, 2015). Since traditional teaching applications possess an extremely normative style in an overbearing manner telling students what to do all the time, it causes failures in the implementation phase (Peng, 2017). Teaching grammar is not a field that gives theoretical information or does not aim to teach students certain definitions and rules (Sagir, 2002). From this point of view rules of a language must be taught co-coordinately with other learning domains and provide integrity among learning domains. Vocabulary teaching was often limited to presenting new items that appeared during reading, or sometimes listening to text (Bozavli, 2017). However, large texts are more effective in improving the existence of students, as they reveal expressions, words, grammar and speech as all text-centered teaching (Yusu, 2014). The grammatical translation approach, the cognitive approach, the communicative approach and the voice-language approach belived the grammatical role in language teaching should play with slight variations (Peng, 2017). The texts in the course books besides developing the reading and comprehending skills of the student make them perceive the rules of the language as well. However the skills of the students, who do not know fundamental concepts for example the sentence structure, will be affected negatively (Rättyä, 2013). This situation besides handicapping the academic success of the individual, whose grammar skills is not adequate; also affect the will of expressing himself or herself in a negative way. In language teaching studies on how texts will be chosen and treated must be carried out and in order to develop language skills learning with text is performed instead of teaching the text (Gunes, 2013). The major part of the grammar teaching is morphology. Morphology; includes knowing the roots that forms the word, existing stems, affixes, with their function and type, and perceiving the functions of these factors (Sagir, 2002). A student who understands morphology and the functions of the affixes enriches his or her vocabulary learning the ways to produce words. Vocabulary, all the words of a language is the total of words that take place in the vocabulary of a person or a society (Korkmaz, 1992).

Lexicology is one of the extensive issues of the language teaching. In order to make the rules that belong to words and words groups be comprehended texts are utilized after theoretical information. The student who learns theoretical information concerning word types develops skills concerning word types instead of memorizing the information making applications with different texts. At this point the goal is to conceive why the word is used for and is to use according to its function. Iscan, explains functional grammar as determining using the task and lexical units of a language in a certain text, why they are used and which function they fulfill (2007). Functional grammar besides analyzing the structures of fundamental linguistic unit as rhetoric tools reveals the ability of learners in defining and performing linguistic units (Xu \& Zhang, 2015). In addition to how written and spoken language is functioned in different social condition is being emphasized, explaining how texts work beyond the sentence level, how different texts are structured and indicating how it changes according to the users of the language, an explanatory approach is adopted (Feng, 2013). Lexicology must be given according to the purpose of use in the sentence, it must be conceived that the function of the word can change depending on syntax. Word types not only must be given by names; the students must feel existence-name relation, existence-quality/determinative (adjective) relation, existence-succession (pronoun) relation, verb-condition/time/place/amount etc. (adverb) relations continuously (Sagir, 2002). Hence in forming sentences they use the types of words according to their place and function. The student, who acquire lexicological information and use the word and word groups appropriately, can make correct expressions in terms of language. Through correct instructions of the teachers the students can make it out of linguistic uses in sentence level from context and then carry out regarding rules to real situations (Bao \& Sun, 2010).

Semantic processing is necessarily involved in deciding if a sentence is grammatical or not (Gutiérrez, 2017). Meaning; is what is understood from a word, statement, behaviour and phenomenon, deduction; semantics on the other hand is the field of science that examines words in terms of their meanings, features and meaning events (Sagir, 2002). The student who conceives the meaning features of the language can convey his or her thoughts with a rich expression as long as s/he pays attention to orthographic rules. A great number of studies were carried out on the beliefs of teachers about teaching grammar, and it was seen that some of them defined it as teaching rules, some defined as a form that provide a basis for use, and some of them as a tool in expressing the meaning (Alghanmi \& Shukri, 2016). At this point 
no matter what our intention is for realizing grammar teaching, this situation does not change the place and importance of grammar in language teaching. It is thought that it is not probable for students to learn and use the language well without good grammar knowledge (Irzawati \& Asiah, 2013).

\section{Methodology}

This research, in which interview technique was used, is phenomenological type from qualitative patterns. It is a research pattern originating from philosophy and psychology realized in order to describe common meaning of experiences regarding a phenomenon (Creswell, 2016b; 2016a). In such researches trust and empathy centered interviews are made for determining the experiences and meanings regarding phenomena (Buyukozturk, Kilic Cakmak, Akgun, Karadeniz \& Demirel, 2014). Qualitative studies are carried out in three ways which are interviews performed with open ended questions, direct observations and written document analysis; and with content analysis the experiences and perceptions of the participators are attempted to determine (Patton, 2014). The study group of the research consists of 5 female and 5 male totally 10 Turkish language teachers who work in the city centre of Elazig. When it is convinced that adequate data is gathered the sample process is completed. In conclusion in qualitative researches, in which interview technique is used, the magnitude and multitude of sample number is not important yet whether the data gathered from the sample fulfils the information amount needed (Turnuklu, 2000). All of the teachers participated in the research work for the government and they have 1-15 years of experience in teaching.

Table 1. Information of the participators

\begin{tabular}{lll}
\hline \multirow{2}{*}{ Gender } & Female & 5 \\
& Male & 5 \\
\hline \multirow{2}{*}{ Education state } & Graduate & 8 \\
& Postgraduate & 2 \\
\hline \multirow{2}{*}{ Service period } & $1-5$ years & 4 \\
& $6-10$ years & 3 \\
\hline
\end{tabular}

\section{Research Goal}

The purpose of this study is to determine the views of teachers regarding grammar teaching in elementary school secondary stage Turkish lessons. For this general purpose it is aimed to determine the views on text based grammar teaching, grammar activities in workbook, enriching the vocabulary of the students, acquiring orthographic skills, conceiving the structure features of the words, acquiring knowledge and skills on word types and syntax, the standard use of language and conceiving meaning features.

\section{The Development of Data Gathering Tools}

Within the research a 10 question interview form was used as data gathering tool. In one on one interview, through the information, opinion, behavior and attitudes of the participators it was attempted to determine together with their reasons recording the data (Karasar, 2009). In order to make the interviews productive it was aimed to develop the participators idea variety and different point of views; it was demanded to provide independent thinking with open ended questions. In order to realize semi structured interviews the participators were addressed follow-up questions when it was needed. While developing the items in the concerning interview form firstly literature was scanned and a draft was developed. It was aimed to concrete the different dimensions of the research phenomenon of each item within this draft scale. The draft scale was presented to the views and evaluations of 5 Turkish language teachers, who work actively, in order to determine the deficiencies and inadequacies. In addition content validity was attempted to provide presenting the views and evaluations of academic members who work in Firat University and Kilis 7 Aralik Universitiy. Considering the views and evaluations of the participators and academic members the scale was finalized and was ready to be used in the interviews.

\section{Analyzing of Data}

The data obtained from the one on one interviews carried out, were written by the researchers on computer. Within this research which was carried out in qualitative pattern content and descriptive analysis were used for the analysis of the data. Within these types of researches coding, separating into fractions, labelling each unit determined and based on the participators' own words, the expressions of the researchers and concepts used in social studies it is aimed to group the codes determined under themes (Creswell \& Plano Clark, 2015). Similar answers were categorized bringing together, the frequency of the answers in all replies were indicated in tables and concerning frequency was interpreted right under the tables.

In order to enable the transmissibility of the research the participators were informed about the process in a detailed way. After recording the data which was written was read to the participators, checked and by this way the credibility of the research was provided. As a result of the coding performance carried out independently by two different 
researchers, the analogous codes were divided into analogous and disparate codes and then multiplied by 100 and concord percentage was evaluated as $82 \%$ and this result was considered adequate in terms of "coder reliability" (Miles \& Huberman, 2016). Coder reliability is defined as coding the same text in the same way by different coders independently or coding of the same text by the same coder in the same way at different times. On the other hand category reliability is categories' being clear and accurate (Bilgin, 2014). Therefore literature was utilized in order to enable categories that were created by the researchers, be clear, accurate and intelligible. Ultimately, in such qualitative researches coder and categorizing reliability is quite important (Sonmez \& Alacapinar, 2016).

\section{Findings / Results}

In this part of the research in accordance with the sub-purposes determined the findings determined was analyzed with content analysis method and categorized:

Table 2. The participators' views regarding text based grammar teaching

\begin{tabular}{lcc}
\hline \multicolumn{2}{c}{ Table } & f \\
\hline Text based grammar teaching & Positive & Negative \\
\hline Text based teaching & 9 & 3 \\
Concreting & 4 & - \\
Association of learning domains & 2 & - \\
Activity based teaching & 2 & - \\
Vocabulary & 1 & 1 \\
Teachers' qualification & 1 & 3 \\
Accordance to the child & - & 2 \\
Adumbration method & 1 & - \\
Integrative approach & 1 & - \\
Cognitive skills & - & 1 \\
Use of theoretical information & 1 & - \\
\hline
\end{tabular}

P-5. In order to enable the child acquire fundamental language skills on the basis of a text is important in terms of the student's seeing a concrete example. It is important in terms of reinforcing the information learned in theory on a text. However the texts chosen must be adequate in terms of grammar. The texts from the valuable works of the poets and writers, who are important in our literature, can be chosen. The literacy value of the texts and their efficacy in terms of grammar can be discussed.

P-7. No matter how grammar teaching is text based in the program I think it still has not settled yet. There are still some teachers who lecture grammar as a separated course and dictate a separate notebook. The reasons for this can be not being able to adapt new letting the old systems go, teaching style etc. I think it should be given within the text.

P-10. Together with the new curriculum the students are given an application based education which can distinguish the piece from the whole rather than theoretical information. In my opinion it is more useful for students to make applications on a text in which they can make sense of instead of learning grammar theories that can be found almost everywhere.

Besides a part of the participators state that language skills can be acquired with text based grammar teaching they expressed that grammar teaching after reading and comprehension studies is more effective in grammar teaching. Through the help of the texts learning domains can be integrated on the other hand it was stated that the texts in the course books were not qualified enough. The acquisition of language skills through texts causes the questioning of the quality of the texts chosen for course books. Another view emphasized is that the texts chosen were not appropriate to the accordance to the child principle. The works of the poets and writers who are important for our literature do not take place in the course books adequately this situation is considered as negativity. A qualified learning is possible through the implications of grammar rules with the help of the text; however as long as classical methods are followed it is said that teachers cannot go beyond the theoretical part of the language. In addition it was stated that listening texts do not include subjects regarding the acquisition of high level of thinking skills. Whereas grammar teaching which is expected to be performed in a way to integrate four basic language skills must be carried out as text based. At this point teachers must always worry about their teachings and taking feedback about their teaching behaviors constantly must search for the ways to develop classroom applications after recognizing their weak points (Ezzi, 2012). In contemporary world while information and the methods of teaching and learning it change rapidly the teaching occupation which has a dynamic structure cannot close itself to change. Also there are positive thoughts regarding theoretical information that belong to the language can be applied to the texts through the activities that take place in workbooks, the rules that belong to the language can be concrete with the help of the texts and by this way it enables 
active learning. Through constructivist teaching approach giving students a range of activities and application opportunity and the acquisition of independent thinking skill are aimed (Wornyo, 2016).

Table 3. The participators' views regarding "activity based grammar teaching"

\begin{tabular}{lcc}
\hline Activity based grammar teaching & Positive & Negative \\
\hline The number of activities & - & 3 \\
The quality of activities & 1 & 8 \\
Accordance to the child & - & 2 \\
The language used & - & 2 \\
Simplifying teaching & 1 & - \\
Student centered approach & - & 1 \\
Memorization & - & 1 \\
Exam based applications & - & 2 \\
Text-activity rapport & - & 1 \\
Vocabulary & - & 1 \\
Concreting & 1 & - \\
Method preference & - & 1 \\
\hline
\end{tabular}

P-1. The activities in secondary school books provide convenience for the teacher concerning the subjects of grammar being comprehended. However these activities must be prepared more carefully because we come across with faults.

P-2. In order to make the subject reinforced and comprehended better I think it is adequate. However in some activities the questions are not clear and comprehensible enough. In such questions we have to explain how the students must solve the problem again. Even in some activities we score out the question or the example and try to make it clearer with our own words.

P-3. The number of grammar activities is not enough. They cannot be used in terms of making the subject be comprehended. In addition there are some examples wrong. The books must be reviewed again. The same mistake is repeated two years over and over, which shows that the books do not undergo an investigation.

The participators stated that the number of the grammar activities that take place in workbooks is not enough, similar examples are repeated constantly, and there are mistakes in terms of content in the activities, the activities are generally incompatible with the texts, they are unqualified in terms of making grammar skills be comprehended, and inadequate in terms of enriching vocabulary. Since an intelligible language is not used it was stated that the activities are not students centered and therefore they are not appropriate for individual learning. Herein providing introspection opportunity, enable them find their own solutions in learning domains, directing to creative activities, appropriate for developmental features of the students using computer programs in specific and technology in general might be useful (Arulselvi, 2011).The research, which was in experimental pattern, carried out by Naba'h indicates that computer based activities are effective in terms of students' superior visuality, increasing self-confidence, being for several senses. (2012). The use of visual materials appropriate for the content of the lesson and subject make the learning concrete and permanent. Also the negative views regarding the activities are not prepared according to the children, the rules that belong to the language cannot go beyond being abstract are remarked. It was stated that with the wrong method preference the grammar skills are tried to be comprehended with an exam based approach and because of rote learning education learning is not performed exactly. At this point since a lot of teachers possess teacher based perspectives in which students participation does not exist they feel worried in terms of teaching grammar (Corzo, 2013). Since it is the student who is expected to realize learning s/he must take a more active role within the process and learning must be performed with students based approach. Not including activities regarding central exams in the workbooks is another criticism mentioned. Apart from all these views there are positive statements expressing that the activities are qualified, and they simplify grammar teaching. The attitude of constructivist approach to grammar; is to use students based teaching and learning activities that make students active (Wornyo, 2016). The questions in the activities given according to the text; must be such as to motivate the students, draw their attention, direct to studying, clear the subject lectured in mind and develop language and mental skills (Gunes, 2012). Since language skills mostly carried out through texts the grammar rules that will develop and complete language skills must be related with the text (Gocer \& Sayin, 2014). 
Table 4. The participators views regarding "contribution to vocabulary"

\begin{tabular}{lcc}
\hline Vocabulary & \multicolumn{2}{c}{$\mathbf{f}$} \\
\hline Association of learning domains & Positive & Negative \\
Text based teaching & 3 & - \\
Word teaching & 2 & 1 \\
Reading skill & 1 & 4 \\
Use of word & 2 & - \\
Transferring to life & 1 & - \\
Teacher effort & - & - \\
Activity qualification & 1 & 2 \\
Preference of functional words & - & 1 \\
Environmental factors & - & - \\
Repeated activities & 1 & 1 \\
Teaching phrases & - & 2 \\
Cognitive skills & - & 1 \\
Semantic relations & - & 1 \\
\hline
\end{tabular}

P-1. What is essential in developing the vocabulary of the students is the learning the words inferring from the context of the text. The students confirm their guesses with the help of a dictionary. However while teaching grammar the examples given can be used as a tool in developing the vocabulary of the students. Using the spiral learning method in the examples given both the meaning of the word and the meaning of it in the whole sentence can be asked to the students and also the grammar subject can be given.

P-4. It requires high performance of teachers. The shallowness of the course books caused teachers to find different texts. The activities mentioned are left to the mercy of the teacher.

P-9. The repetition of the same activities constantly and the inadequacy of the existing activities are handicaps for the students comprehend these words. The books are inadequate in terms of word number. The students do not have to think about proverbs and idioms. The books presents match activity to have this subject comprehended, instead of this if activities that will lead students think about the subject permanent learning will be performed.

The texts in the course books do not introducing different words to the children; the choice of the texts, the quality of the activities prepared regarding these texts and the repetition of similar activities are the negative opinions the participators mentioned. It was stated that the functional words, that the children can transform into their daily lives, not being included in the word preferences affects the enrichment of the child's vocabulary negatively. This is underlying inefficiency of not being able to express oneself in a correct and effective way. In addition it was said that preferring the match activities based on rote learning without considering the meaning dimension of the idioms and proverbs that enrich the vocabulary of the child, affects high level of thinking and interpreting skill of the child negatively. On the contrary it was remarked that the reading and comprehension studies carried out on texts develops the vocabulary of the child, acquiring language skills integrating learning domains will develop the vocabulary of the child. It was asserted that the acquisitions of these skills will increase according to the effort of the teacher. At this point the teacher can perform application such as class discussions that will increase the participation and motivate the students, speaking competitions, creating a language corner, creating a language club, problem solving activities, role playing etc. (Bao \& Sun, 2010). 
Table 5. The views of the participators regarding "the writing and punctuation skill"

\begin{tabular}{lcc}
\hline The writing and punctuation skill & Positive & Negative \\
\hline Model teacher & 2 & - \\
The quality of the activities & 1 & 2 \\
Memorization & - & 1 \\
Exam based applications & - & 1 \\
Active learning & - & 1 \\
Writing mistakes & - & 2 \\
Writing and punctuation association & 1 & - \\
The number of activities & 1 & 4 \\
Curriculum & 1 & - \\
Learning skill & 1 & 2 \\
Concreting & - & 1 \\
Spiral teaching & 1 & - \\
Content validity & - & 2 \\
\hline
\end{tabular}

P-7. The acquisitions concerning writing and punctuation are available in the curriculum. I think the curriculum can give writing and punctuation adequately however we see that the students have trouble in comprehending orthographic rules. The curriculum must make writing and punctuation subject more concrete.

P-8. By the help of grammar teaching the children try to obey the orthography rules. Although they have difficulty in the beginning since writing and punctuation is mentioned again by the time passes they try to write flawless.

$\mathrm{P}-10$. I think it is adequate in having punctuation marks comprehended. However in the activities within the course books there are not many activities concerning writing and punctuation. Although writing and punctuation is a very extensive subject I think concerning activities are not adequate.

Within the research it was stated that the activities did not include all orthographic skill, the words of which writing is confusing were not included adequately, and from this point of view the activities must be included in the workbooks after expanding each year, exam based and rote education and also the abstractness of the orthographic rules lead to learning difficulties from time to time. It was stated that within the books existing writing mistakes cannot be accepted and the books must be prepared more attentively. Some recommendations were determined regarding the teaching orthography skills in integration, teachers' showing model behaviors, the activities' being qualified and adequate. The punctuation marks; have an important place in language education since they provide determining establishing an exact communication, simplifying the comprehension of writing, parts of speech, distinguishing inner sentence, parenthetical sentence and clause, tune, emphasis and pauses (Uludag, 2002). In the acquisition of orthography skill emphasizing the writing learning domain, the students must be let see their mistakes on the texts they write and they must be provided to learn the correct uses instead of the wrong ones. Writing the words correctly and using punctuation marks in the right places the skill of expressing emotions and ideas by writing effectively must be acquired. If the teachers analyse the mistakes systematically they know what is learned, which strategies are used; and the students can know their weak points analyzing their mistakes (Bao, 2015).

\begin{tabular}{lcc} 
Table 6. The participators views regarding "having constructional characteristics comprehended" \\
\hline Comprehension of structural features & Positive & Negative \\
\hline Word structure & 1 & - \\
Accordance to the child & - & 1 \\
Foreign language effect & - & 1 \\
Syntax & - & 1 \\
Semantic preference & - & 1 \\
The quality of the activities & 3 & 2 \\
Text based teaching & - & 1 \\
Vocabulary & - & 1 \\
Concreting & - & 1 \\
\hline
\end{tabular}


P-1. We meet the structural features of the words in 6th grade as grammar. By the help of this subject the word producing talent of the students is developed.

P-7. I think grammar activities can make students to comprehend the word structure subject. Adequate activities are included regarding this. However if the structure of the word is made more concrete it will be comprehended better.

P-8. While the students are examining the structural characteristics of the words in grammar firstly they try to analyze the words with an approach of just like a scientist.

Within the research negative views were determined such as in the first language education structural information cannot be concreted, the activities appropriate for the accordance to the child principle are not prepared, the text preferences are problematic, the activities are not efficient in making the students comprehend structural information, and inadequacies regarding the use of inverted sentences. The use of the words chosen regarding making the stu dents comprehend structural information of the word out of real terms and the use of foreign words were indicated as other problems. Whereas as a result of a good language education the students will find the opportunity to compare the grammar structure of the target foreign language with their languages and solve problems (Singaravelu, 2014). Within the context of first language while structural information makes students to acquire the skill of producing new words, it must avoid staying uninformed about the foreign words spoken within the period they live. This situation will ease up the foreign language education. On the contrary there are positive views stating that they consider grammar learning domain's activities prepared regarding the comprehension of structural features of the words adequate, together with the word production skill of the children it can enrich their vocabulary. The children who can comprehend the structural features of the words, the functions of the affixes can include new words to their vocabulary acquiring word production skill.

Table 7. The views of the participators regarding "having word types comprehended"

\begin{tabular}{|c|c|c|}
\hline \multirow{2}{*}{ Having word types comprehended } & \multicolumn{2}{|c|}{$\mathbf{f}$} \\
\hline & Positive & Negative \\
\hline Learning habits & 4 & - \\
\hline Functional grammar & 1 & - \\
\hline Accordance to the child & - & 2 \\
\hline Preference of the method & - & 1 \\
\hline Curriculum & - & 2 \\
\hline The quality of the activities & 3 & 2 \\
\hline The use of words in different types & - & 1 \\
\hline Books & 1 & - \\
\hline Social learning & 1 & - \\
\hline Learning by intuition & 1 & - \\
\hline
\end{tabular}

P-1. The students, who learn the word types in the context of grammar, can tell in which it is used as a noun, in which sentence it is an adjective, in which sentence it is adverb or relative clause.

P-4. "The types of the words" that take place in the secondary school curriculum is very important in terms of grammar. However within the intense program I think it is inadequate in teaching the word types. Especially the books and the activities are inadequate in my opinion.

P-7. I think the word types, is the grammar subject comprehended best among the grammar activities. The number and the variety of the activities that will make the students comprehend are included. The information about a word type is included within the teacher's guide rather than the activities. The teacher firstly informs the students about the subject in details, and then conducts the activities. If this process proceeds steadily the students will understand the subject very well.

A part of the participators stated their negative views regarding the quality of the activities chosen, the accordance of these activities to the child, method preference and the use of words in different types. Especially it was stated that the acquisitions that belong to the word types were not planned in the program. Some stated that learning domain of grammar make the students to acquire the information and the skills regarding word types and can make them comprehend the functional features of the words. It was expressed that the students who learn the first language from the social environment can reflect these experiences to the school environment. The researches of first language indicate that the language teaching efforts should not be limited with the explanation of linguistic characteristics within the oral or grammatical context; they oblige the realization of it in an integrated coordinative process in social and cultural context (Xu \& Zhang, 2015). The individuals who learn the first language primarily from the close environment come to school with certain acquisitions and build new acquisitions on this readiness. The quality of the activities that take place in workbooks must enable the child to intuit the word type regarding the use of it in the sentence. In 
conclusion it can be said that the word gains task and meaning within the sentence and for what reason the word is used within the whole is recognized.

Table 8. The participators' views regarding "having syntax skills comprehended"

\begin{tabular}{|c|c|c|}
\hline \multirow{2}{*}{ Having syntax skills comprehended } & \multicolumn{2}{|c|}{$\mathbf{f}$} \\
\hline & Positive & Negative \\
\hline Learning habits & 5 & - \\
\hline Functional grammar & 3 & - \\
\hline Environmental factors & - & 1 \\
\hline First language consciousness & 1 & 1 \\
\hline Pronunciation & - & 1 \\
\hline Syntax skill & - & 2 \\
\hline Ambiguity & - & 1 \\
\hline Preference of inverted sentences & - & 1 \\
\hline Time & - & 1 \\
\hline
\end{tabular}

P-2. The most of the mistakes made by the students regarding the choice of appropriate words are caused by the negative transfers they make from their first languages. First language awareness must be created. The use of words for wrong meaning must be emphasized. In terms of emphasis, pronunciation and appropriateness to the value the words must be uttered and lined up correctly.

P-7. The subject of parts of speech, which is an 8th grade subject, is related with syntax. Several activities are included in this grade. However the subject of syntax can be expanded into a wider process. Thereby the students can comprehend the syntax subject, which is very important for them, better.

P-10. We are planning to have students comprehend making meaningful and regular sentences with the activities that take place in Turkish course and workbooks. Especially the use of adjectives and adverbs appropriately simplifies its being expressed correctly in a written way. At this point I think the students comprehend the skills regarding syntax.

The participators stated that the social environment in which the child lives, pronunciation problems, the preferences and use of sentences, and the time separated for the syntax subject within the program were problematic. While some of them stating positive views regarding information and skills are acquired concerning syntax, especially together with the acquisition of words types skills they expressed that the words are used in the right place within the sentences functionally, and the parts of speech are comprehended accordingly, the activities prepared regarding syntax are adequate and using the first language consciously is provided (Karahan, 2007). The child who learns for which purpose the adjective and adverb are used in the sentence will be able to use word types correctly in terms of syntax.

Table 9. The participators' views regarding "the use of standard/formal language"

\begin{tabular}{lcc}
\hline The use of standard/formal language & Positive & Negative \\
\hline The use of first language & 3 & - \\
Transferring to life & 1 & - \\
The use of dialect & 1 & 3 \\
Active learning & - & 1 \\
First language consciousness & 3 & 2 \\
Reading skill & 1 & - \\
Teacher students cooperation & 1 & - \\
Structural information & - & 2 \\
Intuitional learning & 2 & - \\
Social learning & 1 & - \\
The qualification of the teacher & 1 & - \\
The use of language in the books & 1 & - \\
Foreign language effect & 1 & \\
\hline
\end{tabular}

P-1. After grammar teaching the students, who recognize the written words are not used like this in daily language, can reflect the right into their daily lives. Especially syncopation and speaking with an accent decrease. 
P-3. In every stage of the education-training life we were told to make sentences appropriate for the rules of our language by our teachers. It must be told and we must obey it. I think the most effective way to achieve it, is reading. The individuals who read constantly will make correct sentences both in their speaking and writing. Our education training process must be planned as reading based.

$\mathrm{P}-10$. The student, who is familiar with the standard language that takes place in the texts of the course books, learns to use the language correctly. According to the conditions of the geographic region we live in although some students have little pronunciation problems generally the students who use a standard language adapt language rules.

The participators stated positive views regarding our language reaches a standard use and it can be transferred into daily life together with grammar teaching. They stated that the qualification of the teacher, the dialogue between the teacher and the student, affection for the language, first language consciousness, the correct use of the language in the books, by this way the child's learning the standard language by intuition were effective for our language to be spoken in a standard way. However it was stated that the region lived affects the rules of the language to be learned exactly. The main reason for this situation was indicated as we do not have enough language awareness. Grammar rules are like adhesive in the skills of using the language correctly and effectively; because for effective speaking and writing the knowledge and use of grammar rules are needed (Gocer \& Sayin, 2014). The written or spoken products of every language must obey the rules of word order of that language; grammar teaching includes the central part for teaching and learning a language (Wornyo, 2016). In order to speak and write with a standard language first of all we need grammar rules. By this way we can provide an association in speaking and writing language. Especially regarding writing skills, knowing to what extent, grammar is needed for producing good sentences in writing adventure will be useful for a teacher (Andrews, 2005). On the contrary a positive directional teaching method which establishes an accurate connection between grammar and writing has not been found yet (Myhill, 2005). However the development of writing skills depends on the regular and persistent studies performed. Every attempt for writing will bring us to a better place than where we are.

Table 10. The views of participators regarding "having the meaning properties of the language comprehended"

\begin{tabular}{lcc}
\hline $\begin{array}{l}\text { Having the meaning properties of the language } \\
\text { comprehended }\end{array}$ & Positive & Negative \\
\hline Structural information & 1 & 1 \\
Reading and comprehension skill & - & 3 \\
Word preference & - & 1 \\
Learning habits & 1 & 2 \\
Multi-meaning & 2 & - \\
The quality of the activities & - & 3 \\
The association of learning domains & - & 1 \\
The quality of course books & - & 1 \\
Exam based applications & - & 2 \\
Association with life & 1 & - \\
Systematic approach & 1 & - \\
Conceptual information & - & 1 \\
Accordance to the child & - & 1 \\
\hline
\end{tabular}

P-5. The Turkish language is very rich in terms of meaning. A word can have a meaning more than one. We can use the words that are just learned in grammar teaching in terms of meaning. Likewise we can give the meaning property of the sentence in grammar teaching.

P-7. The students frequently have examinations in their lives. Turkish takes place in almost every exam. $70 \%$ of the Turkish exams are chosen from the questions concerning meaning properties. I think there is not adequate activity regarding having the meaning properties of the language comprehended in workbooks. In recent years one of the reasons for students' being unsuccessful in Turkish lesson exams is this in my opinion.

P-8. The difference of Turkish lesson from other lessons is that it is a part of our daily life. Sometimes when we want to have students comprehend the meaning property of a word the children recognize that they use it in their daily life and start to give examples.

The meaning is each of the concepts the word creates in mind related with other factors within a word, connotation (Korkmaz, 1992). Some of the participators stated negative views regarding lexical properties together with grammar learning domain were not acquired adequately. The words' having different meanings and being concentric in our daily life was stated as an indicator that our language is a living rich language. However the quality of course books and the 
accordance of texts in the books for the child, the reflection of lexical properties of the words, the negativities experienced at the point of developing the conceptual knowledge of the children caused inadequacy in having the lexical properties comprehended. It was expressed that the inadequacy in the acquisition of reading and comprehension skills caused failures in central examinations. Reading and inferring from what is read require high level of thinking skill.

Table 11. The participators' views regarding "grammar teaching"

\begin{tabular}{lcc}
\hline Views and recommendations & Positive & Negative \\
\hline The quality of the activities & - & 1 \\
Reading and comprehension skill & - & 1 \\
The grammar being the purpose & - & 1 \\
Teacher guide books & - & 1 \\
Content mistakes & - & 1 \\
Text choice & - & 2 \\
Speaking skill & - & 1 \\
Writing skill & 1 & - \\
Command of grammar & - & 1 \\
Content validity & - & 1 \\
\hline
\end{tabular}

P-2. Reading, comprehending, interpreting and designing power emphasizing grammar too much should not form a low profile. Grammar must be supportive of the reading process more contributing child mind in a supportive structure.

P-6. Workbooks must be improved. The miswriting of the words, the wrong activity acquisition makes learning more difficult, which is already hard. In teachers' guide books there are wrong information. For the colleagues who start the occupation it is disadvantage.

P-9. In order to develop reading skills the works of outstanding writers and poets must be included instead of long and ordinary text. The number of the activities is adequate for speaking skill however subject variety must be provided. The subjects must enable students to create different ideas. The writing skills are adequate. The grammar activities are inadequate. They must be at a level to make the subject comprehended. The same acquisition should not be repeated.

The participators stated negative views at the points of text choice concerning grammar teaching, the number and the quality of the activities, its reflecting all of the grammar subjects, the repetition of some acquisitions and the quality of the activities regarding speaking and grammar skills. Grammar being considered as a purpose, keeping reading and comprehension skills in the background, the guide books', which were prepared for the purpose of helping teachers, including mistakes in terms of content are the other negative views uttered. One of the participators stated that the activities regarding the acquisition of writing skills were adequate. Especially in the process based writing approach since initiative writing, preparing draft, reviewing and arranging processes are used it is possible to develop the grammar skills of the students who are exposed to significant and related feedback systematically (Cuéllar, 2013). In addition well performed grammar and word teaching will help students improve their writings (Sermsook, Liamnimitr \& Pochakorn, 2017). The students who acquire skills of words and forming sentences provide transferring what they learn to daily life using them especially in writing activities. Teaching grammar is a learning domain we need in the acquisition of all skills regarding speaking and writing the language correctly and effectively and reading and interpreting texts. Within this context language courses must include the development of grammar skills together with fundamental learning domains.

\section{Discussion}

Language, which is a part of common life, has a certain arrangement and this situation emerged some rules. Before starting to school life the individual, who learns the first language from the environment, performs this learning assignment within the scope of a plan together with school. After the individuals start to understand and speak their first language they understand the grammar structure of the language; because the individuals' knowing their first language is only possible through being informed form the language systems that form that language (Erdem \& Celik, 2011). After 1970s language education considered grammar as a problem in terms of directing to communication based teaching, student motivation and success and aimed developing fluent communication as the basic purpose (AlMekhlafi \& Nagaratnam: 2011). On the contrary since grammar rules are like phrases that provide the pieces of a machine function, grammar teaching in language education is a must (Zhang, 2009). Considering language training is performed through texts; teaching the rules and examples that belong to grammar relating with reading/listening texts, will strengthen a language perception that can be integrate with literature and life in the eyes of a child (Gocer \& Sayin, 
2014). The texts that take place in the course books in such a layout, the activities prepared regarding them must be reflecting the grammar properties of the language. However the participators stated that the texts that take place in the course books are determined carelessly, the qualification of the grammar activities prepared according to these texts was not adequate and also they had to carry out alternative studies in addition they expressed that the activities did not include all grammar skills. Therefore in language courses the use of interesting materials like anecdotes, proverbs, short stories, cartoons, caricatures, journal articles, television programs, movies etc. That will draw the students' attention will not only be useful in the compensation of the deficiencies of the course books and will increase the eagerness to learn as well (Thakur, 2015).

Through the texts together with the purpose of enriching the children's vocabulary, we cannot make them meet new words that they can transfer to daily life. In order to perform word teaching the best way correct pronunciation and writing, the correct use of grammar forms, the use of words according to their contextual meaning and learning skill (Mokhtar, 2016). The word level, which will be taught appropriately to the children's age range, must be determined, idioms and proverbs must be comprehended within the scope of a system and the enrichment of vocabulary should be left to chance. If one of the purposes of the first language education is to raise individuals who read, understand what they read and express themselves correctly and effectively, we can only realize this purpose in a planned way.

With a standard/common language together with planning the speaking and writing skills of children the activities regarding the comprehending of orthographic rules are not included in the workbooks adequately. In order to correct the language errors of the students a logical reason cannot be found for the defense of grammar, especially results from the theoretical frame deficiencies within this issue (Myhill, 2005). In the research carried out by Williams it was determined that the open university that will be carried out regarding grammar, especially in adult students group, is necessary for language development and help students recognize their mistakes (2013). The activities in the workbooks especially regarding writing are kept in limited numbers and the existing activities do not reflect the entire subject. Within the course and workbooks it is aimed for children to acquire the writing properties of the words implicitly. However the writing and orthographic errors encountered from time to time within the course books affect the learning skill of the children in a negative way. As a result in order to write correctly in a language knowing the grammar rules is not enough; transferring the word to writing completely and correctly, for the writing to correspond the word it is needed to fill up the writing accepted by everyone with punctuation marks (Uludag, 2002). Therefore the activities, that will make students to acquire writing and punctuation skills together, must be prepared and these skills should not be taught independently. In language education the functional relations of founder elements of a language and the functional linguistic approach in which the choice systems that the language user - just like a computer program presents us in the menu- performs is important (Sun, 2014). Grammar teaching is the process of performing activities that aim to comprehend the sound, form and sentence structures of the language by intuition using some methods and by this way provide them use the language effectively, correctly and properly (Dolunay, 2010).

Teaching type properties of words in a sentence change appropriately to the usage property is a much more effective earning method than making definitions regarding the subject memorized. Teaching the task of the word, why it is used in the sentence requires comprehending the functional properties of words. Together with grammar teaching it was determined that the skills that belong to the word types are acquired however an equal distribution was not indicated within the program. Especially 6th grade Turkish lesson includes a more intensive content in terms of word types. Using the words appropriate for their functional properties requires forming correct sentences in terms of syntax. Within the grammar learning domain it was determined that the children did not have much trouble with acquiring skills regarding syntax, however he allocated time for the subject within the program, the child must be introduced examples in which inverted sentence structures are used more often. Majorly trusting grammar is correct in language production however concentrating on the students that have deficiencies in terms of the cultural and pragmatic side of the language; since concentrating on communication majorly will cause the students who possess fossilized errors be defined as successful students, contemporary education style including programs must be in an eclectic structure (Ahmed \& Alamin, 2012).

Since the rules of the language are the fundamental tools of correct speaking and writing, teaching grammar has a role that supports the development of other language skills in history (Gocer \& Sayin, 2014). Among the people who speak the same language a standard language is very important for the continuance of a healthy communication. However it can be said that the sociocultural texture of the region lived causes the children use the language incorrectly especially during speaking. The researches indicate that the students who do not have qualified and programmed grammar training are more under the risk of fossilization compared to those who have (Zhang, 2009). Since a person cannot communicate successfully without having command of language rules teaching grammar, which does not neglect communicational aspects, must be carried out dialectically (Kong, 2011). Protecting, developing the first language and utilizing from every opportunity it has, is possible through knowing all properties of the language and functioning its delicacies (Demir \& Yapici, 2007). Another issue that the participators mentioned as an important deficiency is the limited number of activities regarding reflecting the lexical properties of the language. Especially while the skills that belong to grammar are emphasized semantics is kept in the background. 
In conclusion in order to speak and write the language correctly and effectively a strong grammar skill is needed. Grammar functions as a rule that makes language output possible and is defined as the chance of being brought together for forming correct sentences (Irzawati \& Asiah, 2013). From this point of view including grammar skill among other learning domains took it out of being abstract. However there are problems at the point of the qualification of the activities that belong to grammar and its including all subjects.

\section{Conclusion and Recommendations}

Within the research during the training of grammar skills which is one of the language education learning domains it was determined that there were some problems in some issues. One of the major problems is the properties of the texts in which first language education is based on. It was stated that the reading and listening texts that take place within the course books were not appropriate for the children and they were not chosen among the qualified examples of the literature in addition these texts were not adequate at the point of teaching new words to the children. Language education must be carried out through desirable texts for reading that reflect the rich vocabulary of our language. Also the words, which can be used in daily life, that are appropriate for every grade must be determined and through these texts the vocabulary of the child must be enhanced. To achieve this use dictionary must be encouraged and the use of the new words learned in the speaking and writing activities must be promoted. Since grammar teaching is carried out through texts the quality of the activities depends on the text. The activities must be qualified enough to reinforce the subject learned. Otherwise the teacher performs a grammar based lesson apart from the workbooks making alternative studies. This situation causes an independent grammar teaching apart from reading, listening, speaking and writing education. Whereas, grammar must be taught considering all learning domains integrated instead of seeing it as a distinct lesson.

In grammar teaching the deficiencies of the students regarding speaking and writing skills must be determined. The child, who learns word, word type and sentence structures, must be provided to learn all these correctly. In addition the usage properties of punctuation marks can be acquired together with writing skill. After examining the children's errors regarding writing and punctuation feedback must be given. The activities that take place in the workbooks regarding writing and punctuation skill must be given together and their number must be increased. The purpose should not be raising individuals who memorize definition/example but cannot separate and apply what they learn on an independent sentence or text. Grammar teaching must be planned in a way that the child will learn actively by intuition and out of being abstract.

\section{References}

Ahmed, S. \& Alamin, A. (2012). The communicative approaches revisited and the relevance of teaching grammar. English Language Teaching. www.ccsenet.org/elt Vol. 5, No.1; January 2012.

Alghanmi, B. \& Shukri, N. (2016). The relationship between teachers' beliefs of grammar instruction and classroom practices in the saudi context. English Language Teaching. ISSN 1916-4742, E-ISSN 1916-4750. Vol. 9, No. 7; 2016.

Al-Mekhlafi, A. M. \& Nagaratnam, R. P. (2011). Difficulties in teaching and learning grammar in an EFL context. International Journal of Instruction. www.e-iji.net p-ISSN 1694-609X. e-ISSN: 1308-1470. July 2011, Vol. 4, No. 2.

Andrews, R. (2005). Knowledge about the teaching of [sentence] grammar: The state of play. English Teaching: Practice and Critique. December, 2005, Volume 4, Number 3, pp. 69-76.

Arulselvi, E. (2011). Effect of instructional media in the learning of English grammar on the achievement of teacher training students at Namakkal district. i-manager's Journal on English Language Teaching. Vol. 1, No. 3, JulySeptember 2011.

Azar, B. (2007). Grammar-based teaching: A practitioner's perspective. TESL-EJ: Teaching English as a Second or Foreign Language. Volume 11, Number 2, September 2007.

Bao, J. \& Sun, J. (2010). English grammatical problems of Chinese undergraduate students. English Language Teaching. www.ccsenet.org/elt. Vol. 3, No. 2; June 2010.

Bao, X. (2015). Senior high school students' errors on the use of relative words. English Language Teaching. ISSN 19164742, E-ISSN 1916-4750. Vol. 8, No. 3; 2015.

Bilgin, N. (2014). Sosyal Bilimlerde Icerik Analizi: Teknikler ve Ornek Calismalar. Ankara: Siyasal Kitabevi.

Bozavli, E. (2017). Effect of phonetic association on lexis learning in natural language context: a comparative study of English, French and Turkish words. Educational Research and Reviews. www.academicjournals.org/ERR. Vol. 12(2), pp. 45-53, 23 January, 2017. Doi: 10.5897/ERR2016.3104

Buyukozturk, S., Kilic Cakmak, E., Akgun, O. E., Karadeniz, S. \& Demirel, F., (2014). Bilimsel arastirma yontemleri. Ankara, Pegem Akademi. 
Corzo, C. C. (2013). Formal grammar instruction: theoretical aspects to contemplate its teaching. PROFILE: ISSUes in Teachers' Proffessional Development. ISSN 1657-0790 (printed), 2256-5760 (online). Vol. 15, No. 2, October 2013.

Creswell, J. W. \& Plano Clark, V. L. (2015). Karma yontem arastirmalari: Tasarimi ve yurutulmesi. (Cev. Edt. Yuksel Dede ve Selcuk Besir Demir), Ankara: Ani yayincilik.

Creswell, J. W. (2016a). Arastirma deseni: Nitel, nicel ve karma yontem yaklasimlari. (Cev. Edt. Selcuk Besir Demir), Ankara: Egiten Kitap

Creswell, J. W. (2016b). Nitel arastirma yontemleri: Bes yaklasima gore nitel arastirma yontemleri. (Cev. Edt. Mesut Butun ve Selcuk Besir Demir), Ankara: Siyasal Kitabevi.

Cuéllar, M. T. A. (2013). Process writing and the development of grammatical competence. HOW, A Colombian Journal for Teachers of English. ISSN 0120-5927. October 2013, pp. 11-35.

Demir, C. \& Yapici, M. (2007). Ana dili olarak Turkcenin ogretimi ve sorunlari. Sosyal Bilimler Dergisi, 9(2), S. 177-192.

Dolunay, S. K. 2010. Dil bilgisi ogretiminin amaci ve onemi. TUBAR-XXVII-Bahar, s. 275-284.

Erdem, I. \& Celik, M. (2011). Dil bilgisi ogretim yontemi uzerine degerlendirmeler. Turkish Studies - International Periodical For The Language, Literature and History of Turkish or Turkic. Vol. 6/1 Winter. p.1030-1041.

Ezzi, N. A. A. (2012). Yemeni teachers' beliefs of grammar teaching and classroom practices. English Language Teaching. ISSN 1916-4742, E-ISSN 1916-4750. Vol. 5, No. 8; 2012.

Fearn, L. \& Farnan, N. (2007). When is a verb? Using functional grammar to teach writing. Journal of Basic Writing. Vol. 26, No. 1, 2007.

Feng, Zhiwen (2013). Functional grammar and its implications for English teaching and learning. English Language Teaching. ISSN 1916-4742, E-ISSN 1916-4750. Vol. 6, no. 10.

Gocer, A. (2015). Temel dil becerilerinin gelistirilmesinde dil bilgisi ogrenme alaninin yeri, islevi ve ogretimi: butunluk ilkesi ve tumevarim yontemi ekseninde tematik bir yaklasim. Egitim ve Ogretim Arastirmalari Dergisi. ss. 233-242.

Gocer, A. \& Sayin, H. (2014). 6, 7 ve 8. sinif Turkce kilavuz kitaplarindaki metinlerin dil bilgisi ogretimindeki yeterliligi ve kullanim durumlarinin incelenmesi. Journal of European Education JEE. ISSN 2146-2674, Vol. 4 Issue 2, s.11-28.

Gutiérrez, X. (2017). Explicit knowledge of the Spanish subjunctive and accurate use in discrete-point, oral production, and written production measures. Canadian Journal of Applied Linguistics. 20, 1 (2017): 1-30

Gunes, F. (2012). Testlerden etkinliklere Turkce ogretimi. Dil ve Edebiyat Egitimi Dergisi. Cilt 1, Sayi 1, S. 31-42.

Gunes, F. (2013). Turkcede metin ogretimi yerine metinle ogrenme. Adiyaman Universitesi Sosyal Bilimler Enstitusu Dergisi Turkcenin Egitimi Ogretimi Ozel Sayisi. Sayi 11, S. 605-637.

Huang, J. (2010). Grammar instruction for adult English language learners: a task-based learning framework. Journal of Adult Education. Vol. 39, No. 1, 2010.

Irzawati, I. \& Asiah, N. (2013). Using webquest in learning grammar: students' perceptions in higher education. Advances in Language and Literary Studies. Vol. 4, No. 1; January 2013.

Imer, K., Kocaman, A., Ozsoy, A. S. (2013). Dilbilim sozlugu. Istanbul, Bogazici Universitesi Yayinevi.

Iscan, A. (2007). Islevsel dil bilgisinin Turkce ogretimindeki yeri. Ataturk Universitesi Sosyal Bilimler Enstitusu Dergisi. Sayi 1, ss. 253-258.

Karahan, L. (2007). Turkcede soz dizimi. Ankara, Akcag.

Karasar, N. (2009). Bilimsel arastirma yontemi. Ankara, Nobel Yayincilik.

Kong, N. (2011). Establishing a comprehensive English teaching pattern combining the communicative teaching method and the grammar-translation method. English Language Teaching. www.ccsenet.org/elt Vol. 4, No. 1; March 2011.

Korkmaz, Z. (1992). Gramer terimleri sozlugu. Ankara, TDK.

Li, Z. \& Song, M. (2007). The relationship between traditional English grammar teaching and communicative language teaching. US-China Education Review. ISSN1548-6613, USA. Volume 4, No. 1 (Serial No. 26), Jan. 2007.

Miles, M. B. \& Huberman, A. M. (2016). Genisletilmis bir kaynak kitap: Nitel veri analizi. (Cev.: S. A. Altun, A. Ersoy). Ankara, Pegem Akademi. 
Mokhtar, F. A. (2016). Rethinking conventional teaching in language learning and proposing edmodo as intervention: a qualitative analysis. MOJET: Malaysian Online Journal of Educational Technology. Volume 4, Issue 2.

Myhill, D. (2005). Ways of knowing: writing with grammar in mind. English Teaching: Practice and Critique. December. 2005, Volume 4, Number 3, pp. 77-96.

Naba'h, A. M A. (2012). The impact of computer assisted grammar teaching on EFL pupils' performance in Jordan. International Journal of Education and Development using Information and Communication Technology (IJEDICT). Vol. 8, Issue 1, pp. 71-90.

Patton, M. Q. (2014). Nitel arastirma ve degerlendirme yontemleri. (Cev.: M. Butun, S. B. Demir) Ankara: Pegem Akademi.

Peng, Y. (2017). A survey of grammar instruction from scholastic perspective. English language teaching. ISSN 19164742, E-ISSN 1916-4750, Vol. 10, No. 5; 2017.

Rättyä, K. (2013). Languaging and visualisation method for grammar teaching: a conceptual change theory perspective. English Teaching: Practice and Critique. December, 2013, Volume 12, Number 3, pp. 87-101.

Sagir, M. (2002). Ilkogretim okullarinda Turkce dil bilgisi ogretimi. Ankara, Nobel.

Sermsook, K, Liamnimitr, J. \& Pochakorn, R. (2017). An analysis of errors in written English sentences: a case study of Thai EFL students. English Language Teaching. ISSN 1916-4742, E-ISSN 1916-4750. Vol. 10, No. 3; 2017.

Singaravelu, G. (2014). Impact of gadget based learning of grammar in English at standard II. i-manager's Journal on English Language Teaching. Vol. 4, No. 2, April-June 2014.

Solikhah, I. (2017). Corrections on grammar, sentence variety and developing detail to qualify academic essay of Indonesian learners. Dinamika Ilmu. Volume 17 (1), 2017.

Sonmez, V. \& Alacapinar, F. G. (2016). Sosyal bilimlerde olcme araci hazirlama. Ankara: Ani Yayincilik.

Sun, X. (2014). Ungrammatical patterns in chinese EFL learners' free writing. English Language Teaching. ISSN 19164742, E-ISSN 1916-4750. Vol. 7, No. 3; 2014.

Thakur, V. S. (2015). Using supplementary materials in the teaching of English: pedagogic scope and applications. English Language Teaching. ISSN 1916-4742, E-ISSN 1916-4750. Vol. 8, No. 12; 2015.

Turkce Sozluk. (2009). TDK s.529

Turnuklu, A. (2000). Egitimbilim arastirmalarinda etkin olarak kullanilabilecek nitel bir arastirma teknigi: gorusme. Kuram ve Uygulamada Egitim Yonetimi. Sayi: 24, Guz 2000, ss. 543-559.

Uludag, E. (2002). Ilkogretim ikinci kademe ogrencilerinin yazim ve noktalama kurallarini uygulama beceri duzeyleri. Erzincan Egitim Fakultesi Dergisi. Cilt-Sayi: 4-1, S. 97-114.

Vardar, B., Guz, N. Huber, E. Senemoglu, O. \& Oztokat, E. (2002). Aciklamali dilbilim terimleri sozlugu. Istanbul, Multilingual. 